\title{
Water extractable plant nutrients in soils amended with cow manure co-composted with maple tree residues
}

\author{
Zobia Anwar ${ }^{1}$, Muhammad Irshad ${ }^{1,2}$, An Ping ${ }^{2}$, Farhan Hafeez ${ }^{1}$, Shao Yang ${ }^{2}$ \\ (1. Department of Environmental Sciences, COMSATS University Islamabad, Abbottabad Campus, Abbottabad 22060, Pakistan; \\ 2. Arid Land Research Center, Tottori University, Hamasaka cho Tottori 680-0001, Japan)
}

\begin{abstract}
Studies on the availability of plant nutrients in soils treated with manure co-composted feed-stocks are very rare. The present investigation aimed at studying the nutrient release pattern from three soils amended with maple tree leaves co-composted with cow manure. Soils were mixed with the compost at the rate of $20 \mathrm{t} / \mathrm{hm}^{2}$ and incubated at room temperature. Prior to incubation, plants residue samples were analyzed for total elemental concentrations $\left(\mathrm{NO}_{3}, \mathrm{NH}_{4}, \mathrm{P}, \mathrm{K}, \mathrm{Ca}, \mathrm{Mg}, \mathrm{Na}, \mathrm{Zn}\right.$, $\mathrm{Mn}, \mathrm{Fe}, \mathrm{Cu}, \mathrm{Ni}$ and $\mathrm{Cd}$ ). Water extractability of nutrients from soils was affected by the type of soil and ratio of composted manure applied. Extractable $\mathrm{NH}_{4}, \mathrm{P}, \mathrm{K}, \mathrm{Ca}$ and $\mathrm{Mg}$ concentrations varied in the descending order of sandy clay, sandy loam and silt loam except $\mathrm{NO}_{3}$. The concentrations of $\mathrm{P}, \mathrm{K}, \mathrm{Ca}$ and $\mathrm{Mg}$ in the amended soils increased with the ratio of manure co-composted with leaf litter while those of $\mathrm{NO}_{3}, \mathrm{NH}_{4}$ and trace elements decreased. The residual nutrients in soil varied directly with their contents in the compost amendments. Co-composting improved the availability of nutrients in soils and this should be an ideal approach to managing the enormous waste generated from the livestock sector for restoring soil fertility.

Keywords: macro-elements, micro-elements, varied textured soils, co-composting, cow manure, maple plant residues DOI: $10.25165 /$ j.ijabe.20181105.3494
\end{abstract}

Citation: Anwar Z, Irshad M, Ping A, Hafeez F, Yang S. Water extractable plant nutrients in soils amended with cow manure co-composted with maple tree residues. Int J Agric \& Biol Eng, 2018; 11(5): 167-173.

\section{Introduction}

Livestock manure is a valuable nutrient source when applied to the soil at rates that consistent with good agronomic practices ${ }^{[1]}$. Irshad et al. ${ }^{[2]}$ reported that increasing application of composted manure profoundly increased the nutrients uptake by plants for better growth. The quantity of organic materials added to the soil is determined and controlled by either natural returns through roots, stubbles, sloughed-off root nodules and root exudates or organic manures. In recent times, organic manures as a substitute to mineral fertilizers and as a rich source of plant nutrients has gained worldwide concern due to rising costs of mineral fertilizers, rapid nutrient loss from fertilizers addition and the attendant adverse environmental impacts of inorganic fertilizers. Bioaccumulation of macronutrients, particularly nitrogen, phosphorus and micronutrients in soils, increases the potential risk of the bio-amplification and contamination of food chain being triggered by the potential degradation of surface and ground water resources via leaching of toxic elements, nutrient imbalances, and phytotoxicity in crops ${ }^{[3,4]}$.

The increased environmental pollution has stimulated studies into identifying environmentally sound and economically feasible

Received date: $2017-05-16 \quad$ Accepted date: 2018-04-22

Biographies: Zobia Anwar, PhD candidate, research interest: recycling of organic waste, Email: zobiaanwar@ciit.net.pk; An Ping, Associate Professor, research interests: biochemical and physiological characterization of plants under salt stress, Email: an.ping@alrc.tottori-u.ac.jp; Farhan Hafeez, Assistant Professor, research interests: soil microbiology, Email: drfarhan@ciit.net.pk; Shao Yang, $\mathrm{PhD}$ candidate, research interests: biochemistry and physiology of plants under salt stress, Email: D16A4001Z@edu.tottori-u.ac.jp.

*Corresponding author: Muhammad Irshad, Professor, research interest: environmental soil science. Department of Environmental Sciences, COMSATS University Islamabad Abbottabad Campus 22060, Pakistan. Tel: +92-992383591, Fax: +92-992-3835925, Email: mirshad@ciit.net.pk. technologies for animal waste management. Issues associated with raw manure application to the fields could be mitigated by stabilizing soluble nutrients to more stable organic forms before its application to the soil. Among the available technologies for solid waste management, composting has been considered to be the most preferred method and often presented as a low-technology and low-investment process for the safe disposal of solid waste. A useful resource of organic fertilizer is regenerated and in this way environmental degradation could be curtailed ${ }^{[5-7]}$. Co-composting is a preferred method of turning wastes and organic by-products into higher nutrient end-products and to reduce the mobility of heavy metals in composting mixtures ${ }^{[8-10]}$.

Tree litter may be an ideal amendment for nutrient conservation and heavy metal stabilization. Studies have shown that it could be used as soil conditioner to enhances crop yield and plant growth by retaining and supplying nutrients when co-composted with manure ${ }^{[11]}$. A better understanding of amendment effects should help farmers design more rational systems for composting manures and optimizing costs associated with operating composting systems ${ }^{[12]}$. Amongst the controllable factors influencing manure composting, the selection of an appropriate bulking agent had a significant effect on manure composting substrate properties (moisture, porosity, $\mathrm{C} / \mathrm{N}$ ratio, $\mathrm{pH})^{[13]}$. There are a lot of bulking agents that could be used as a carbon source but the choice is made based on the availability of a specific bulking agent, although some of the available agents have less readily degradable carbon source ${ }^{[14]}$. The C:N ratio of litter usually varies with the type and quantity of litter materials used. The main reason for choosing tree-waste (mixture of tree residues) as a bulking agent is its large availability in cities. Co-composting animal manure with tree wastes could offer several environmental and economic benefits. However, available nutrients undergo a variety of transformations during the composting, and the information on the availability of plant 
nutrients after application of co-composted plant leaf residues with cow manure at different ratios to soils has not been well documented. Therefore, this study was designed to investigate nutrient availability from soils applied with cow manure co-composted with maple tree litter.

\section{Materials and methods}

\subsection{Collection of organic waste}

Cow dung was collected from local farms; tree litter [from maple (Platanus orientalis L.) was collected from various locations in Abbottabad city $\left(34.1558^{\circ} \mathrm{N}, 73.2194^{\circ} \mathrm{E}\right)$, Pakistan. Before composting, air dried tree litter was manually chopped to approximately $2-3 \mathrm{~cm}$.

\subsection{Co-composting process}

Composting piles were set up where cow manure (CM) was treated with chopped maple tree additives to optimize the co-composting process. Cow manure was co-composted with maple tree residues (MR) in plastic composting bins (15 L). The materials were mixed at 1:0, 1:1, 1:2 and 1:3 ratios of CM: MR and co-composted for 120 d. Each treatment was conducted in triplicate. During the co-composting process, samples were occasionally pulverized and moistened to approximately $20 \%$ at room temperature under aerobic conditions. Samples were collected after $120 \mathrm{~d}$ of composting, air dried and passed through a $2 \mathrm{~mm}$ sieve for the analysis of relevant parameters (Table 1). Total carbon was determined by dry combustion method ${ }^{[15]}$. Total organic matter content was calculated by multiplying the total carbon values by $1.72^{[15]}$. Manure samples were milled and digested in a mixture (3:1) of nitric $\left(\mathrm{HNO}_{3}\right)$ and perchloric $\left(\mathrm{HClO}_{4}\right)$ acids to determine the total concentrations of elements ${ }^{[16]}$. Total $\mathrm{N}$ was determined using Kjeldahl method. The $\mathrm{P}$ was determined on a spectrophotometer using the phosphomolybdate blue method. Absorbance was determined at a wavelength of $710 \mathrm{~nm}^{[15]}$. The $\mathrm{pH}$ of organic manures and soils samples were measured in water-manure and water-soil suspensions of 1:5 ratio with $\mathrm{pH}$ (Janway 3505) and EC (Janway 470) meters.

Table 1 Chemical composition of manure co-composted with maple tree litter at different ratios

\begin{tabular}{|c|c|c|c|c|}
\hline Parameters & $1: 0$ & $1: 1$ & $1: 2$ & $1: 3$ \\
\hline Total C/g $\cdot \mathrm{kg}^{-1}$ & 366.8 & 375.4 & 378.8 & 395.8 \\
\hline Total N/g $\cdot \mathrm{kg}^{-1}$ & 17.2 & 14.4 & 13.8 & 11.6 \\
\hline $\mathrm{C} / \mathrm{N}$ & 21.3 & 26.1 & 27.4 & 34.1 \\
\hline $\mathrm{NO}_{3} / \mathrm{mg} \cdot \mathrm{kg}^{-1}$ & 91.6 & 86.8 & 74.5 & 67.9 \\
\hline $\mathrm{NH}_{4} / \mathrm{mg} \cdot \mathrm{kg}^{-1}$ & 59.6 & 56.8 & 54.5 & 37.9 \\
\hline Total P/mg $\cdot \mathrm{kg}^{-1}$ & 167.7 & 175.7 & 187.8 & 207.8 \\
\hline Total $\mathrm{Ca} / \mathrm{mg} \cdot \mathrm{kg}^{-1}$ & 167.2 & 188.4 & 198.6 & 212.3 \\
\hline Total Mg/mg $\mathrm{kg}^{-1}$ & 132.6 & 148.6 & 161.6 & 179.2 \\
\hline Total K/mg $\cdot \mathrm{kg}^{-1}$ & 400.4 & 467.8 & 475.8 & 491.3 \\
\hline Total Na/mg $\cdot \mathrm{kg}^{-1}$ & 45.6 & 45.0 & 35.6 & 30.7 \\
\hline Total Cu/mg $\mathrm{kg}^{-1}$ & 93.1 & 84.5 & 76.7 & 66.8 \\
\hline Total $\mathrm{Fe} / \mathrm{mg} \cdot \mathrm{kg}^{-1}$ & 184.9 & 178.8 & 171.6 & 162.6 \\
\hline Total Mn/mg $\mathrm{kg}^{-1}$ & 124.8 & 115.5 & 108.5 & 102.3 \\
\hline Total Zn/mg $\mathrm{kg}^{-1}$ & 140.6 & 122.7 & 106.9 & 86.7 \\
\hline Total Ni/mg $\cdot \mathrm{kg}^{-1}$ & 2.7 & 2.4 & 2.5 & 2.1 \\
\hline Total Cd/mg $\mathrm{kg}^{-1}$ & 1.5 & 1.1 & 1.2 & 0.8 \\
\hline $\mathrm{EC}(1: 5) / \mathrm{dS} \cdot \mathrm{m}^{-1}$ & 5.0 & 5.3 & 5.6 & 5.9 \\
\hline $\mathrm{pH}(1: 5)$ & 8.7 & 8.2 & 8.0 & 7.8 \\
\hline
\end{tabular}

2.3 Soil incubation

Three types of soils (sandy loam, silt loam and sandy clay) were sampled at a depth of $0-20 \mathrm{~cm}$ from different sites in Abbottabad, Pakistan. The samples were air-dried for $2 \mathrm{~d}$ and screened by passing through a $2 \mathrm{~mm}$ sieve. The physico-chemical properties of soils using standard analyze procedures are given in Table 2. $250 \mathrm{~g}$ of each soil type was taken in a plastic bag and amended with the co-composted material at four ratios (1:0, 1:1, $1: 2$ and 1:3) by thoroughly mixing with these soils at the rate of $20 \mathrm{t} / \mathrm{hm}^{2}$ (based on 2 million kg soil per plow layer $(20 \mathrm{~cm})$ per $\mathrm{hm}^{2}$ ). Co-composted manures applied to three soils were compared with the soil applied with composted cow manure without plant litter (1:0) which was considered as control treatment. The experiment was a $(4 \times 3)$ factorial (ratio of cow manure co-composted with plant residues $\mathrm{x}$ soil types) resulting in 12 experimental units, arranged into a completely randomized design replicated three times. The amended soils were incubated at room temperature $\left(25^{\circ} \mathrm{C}-30^{\circ} \mathrm{C}\right)$ in loosely covered plastic bags for a period of four weeks. Occasionally soil samples were moistened with distilled water and the water contents were maintained at approximately $20 \%$ (on air dry weight basis). After incubation, soil samples were taken from each treatment, dried and analyzed for $\mathrm{pH}$, electrical conductivity (EC), total organic carbon, nitrate $\left(\mathrm{NO}_{3}{ }^{-}\right)$, ammonium $\left(\mathrm{NH}_{4}^{+}\right)$, phosphorus $(\mathrm{P})$, potassium $(\mathrm{K})$, calcium $(\mathrm{Ca})$, magnesium $(\mathrm{Mg})$, sodium $(\mathrm{Na})$, copper $(\mathrm{Cu})$, iron $(\mathrm{Fe})$, manganese $(\mathrm{Mn})$, zinc $(\mathrm{Zn})$, nickel $(\mathrm{Ni})$ and cadmium $(\mathrm{Cd})$. Ammonium and $\mathrm{NO}_{3}-\mathrm{N}$ were extracted from the manure and soil samples with $2 \mathrm{M} \mathrm{KCl}$ (1:5 soil/KCl volume). Ammonium- $\mathrm{N}$ was determined following the indophenol blue method whereas the $\mathrm{NO}_{3}-\mathrm{N}$ was determined as described by Anderson and Ingram ${ }^{[17]}$ and read from the spectrophotometer at 635 and $410 \mathrm{~nm}$, respectively. The $\mathrm{pH}$ of organic manures and soil samples was measured in water-manure suspensions and water-soil suspensions of $1: 5$ ratio with $\mathrm{pH}$ and EC meters. To determine extractable nutrients in the amended soil, $10 \mathrm{~g}$ oven-dried samples were shaken with $100 \mathrm{~mL}$ distilled water on a mechanical shaker for $2 \mathrm{~h}$. The filtrate was used to determine water soluble elements using an atomic absorption spectrometer (Model AAnalyst 700, Perkin-Elmer, Waltham, MA, USA). Results of all determinations were expressed per dry weight of soil.

Table 2 Chemical composition of soils used for the experiment

\begin{tabular}{|c|c|c|c|}
\hline Parameters & Sandy loam soil & Silt loam soil & Sandy clay soil \\
\hline Total C/g $\mathrm{kg}^{-1}$ & 25.6 & 28.3 & 35.7 \\
\hline Total N/mg $\cdot \mathrm{kg}^{-1}$ & 35.8 & 56.6 & 67.8 \\
\hline $\mathrm{NO}_{3} / \mathrm{mg} \cdot \mathrm{kg}^{-1}$ & 6.6 & 15.3 & 10.7 \\
\hline $\mathrm{NH}_{4} / \mathrm{mg} \cdot \mathrm{kg}^{-1}$ & 8.2 & 10.8 & 9.5 \\
\hline Total P/mg $\cdot \mathrm{kg}^{-1}$ & 45.7 & 67.8 & 87.4 \\
\hline Total Ca/mg $\cdot \mathrm{kg}^{-1}$ & 218.7 & 267.8 & 312.6 \\
\hline Total $\mathrm{Mg} / \mathrm{mg} \cdot \mathrm{kg}^{-1}$ & 128.6 & 131.6 & 159.6 \\
\hline Total K/mg $\cdot \mathrm{kg}^{-1}$ & 147.8 & 158.8 & 165.6 \\
\hline Total $\mathrm{Na} / \mathrm{mg} \cdot \mathrm{kg}^{-1}$ & 23.4 & 34.6 & 41.6 \\
\hline Total $\mathrm{Cu} / \mathrm{mg} \cdot \mathrm{kg}^{-1}$ & 34.5 & 56.4 & 65.7 \\
\hline Total $\mathrm{Fe} / \mathrm{mg} \cdot \mathrm{kg}^{-1}$ & 67.8 & 78.6 & 75.6 \\
\hline Total Mn/mg $\cdot \mathrm{kg}^{-1}$ & 47.5 & 67.5 & 78.5 \\
\hline Total Zn/mg kg $^{-1}$ & 56.7 & 76.9 & 112.0 \\
\hline Total Ni/mg $\cdot \mathrm{kg}^{-1}$ & 2.5 & 2.8 & 2.9 \\
\hline Total Cd/mg $\cdot \mathrm{kg}^{-1}$ & 0.3 & 0.9 & 1.0 \\
\hline EC $(1: 5) / d S \cdot m^{-1}$ & 0.5 & 0.4 & 0.7 \\
\hline $\mathrm{pH}(1: 5)$ & 7.6 & 7.8 & 7.2 \\
\hline
\end{tabular}

2.4 Statistical analysis

Data were statistically analyzed using analysis of variance with 
Stat-view software. Mean separation was done using the least significant difference (LSD) test at $p<0.05$. Correlation was determined between water extractable elements in the soils and the total amount of these elements in the co-composted manure.

\section{Results and discussion}

\subsection{Macronutrients}

The chemical properties of the soils and composted manures are given in Tables 1 and 2. Nitrate and $\mathrm{NH}_{4}-\mathrm{N}$ varied with soil and ratio of waste material used for co-compost (Figure 1a). The $\mathrm{NO}_{3}-\mathrm{N}$ concentration significantly reduced with the application of compost with increasing amount of plant litter. Nitrate concentration in treated soils varied in the descending order of 1:0, $1: 1,1: 2,1: 3$. Lower concentrations of $\mathrm{NO}_{3}-\mathrm{N}$ with increased amounts of added leaf litter were partially attributed to simple dilution. The mean $\mathrm{NO}_{3}-\mathrm{N}$ levels in the soil were 8.3 in sandy loam, 10.8 in silt loam and $9 \mathrm{mg} / \mathrm{kg}$ in sandy clay soil, indicating slight differences among the soils. The low $\mathrm{NO}_{3}-\mathrm{N}$ in soil treated with compost containing elevated ratios of plant litter could be due to immobilization of accumulated $\mathrm{NO}_{3}-\mathrm{N}$ or denitrification of mobilized $\mathrm{NO}_{3}-\mathrm{N}$ during incubation. Ammonium $\mathrm{N}$ in soil was negatively associated with the amount of plant litter in the co-compost (Figure 1b). Soils treated with co-compost showed significantly reduced $\mathrm{NH}_{4}$ release than those treated with cow manure without leaf litter. Ammonium concentration in soil decreased as the amount of leaf litter increased to the initial mixture of compost treatment. Soils treated with only manure consistently had the highest level of $\mathrm{NH}_{4}-\mathrm{N}$. Lower residual concentrations of $\mathrm{NH}_{4}-\mathrm{N}$ in soils may be attributed to the increased volatilization losses and/or immobilization of $\mathrm{NH}_{4}$ after application of manure mixture with leaf litter. The increase in the C: $\mathrm{N}$ ratio with greater amount of leaf litter in manure amendment suggests that $\mathrm{N}$ immobilization is likely to cause the decrease in $\mathrm{NH}_{4}-\mathrm{N}$.

In general, the availability of the $\mathrm{P}$ in soil increased after manure amendment. The highest available $\mathrm{P}$ concentration in soil was observed when the higher amount of plant litter (1:3 mixture) was applied. The compost amendment increased soil available $\mathrm{P}$ by $11 \%, 29 \%$ and $37 \%$ in sandy loam soil at ratios of $1: 1,1: 2$ and 1:3 (Figure 1c). Phosphorus increased in the silt loam soil by $30 \%, 56 \%$ and $66 \%$ after the application of leaf residues co-composted at the ratio of 1:1, 1:2 and 1:3 with cow manure. In sandy clay soil it increased by $45 \%, 58 \%$ and $90 \%$, respectively. Swift et al. ${ }^{[18]}$ hypothesized that the $\mathrm{C} / \mathrm{N}$ element ratio in a resource and decomposition biomass are the main factors determining the presence or absence of an accumulation phase of nutrients in the substrate.

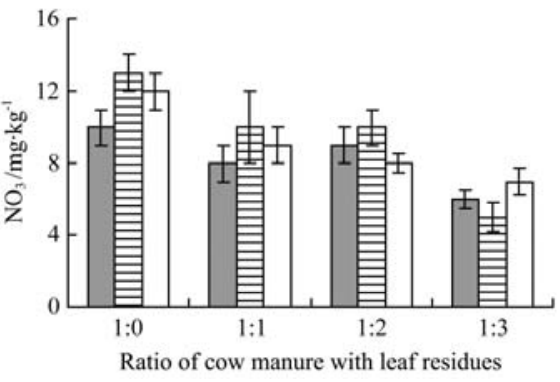

a. $\mathrm{NO}_{3}$

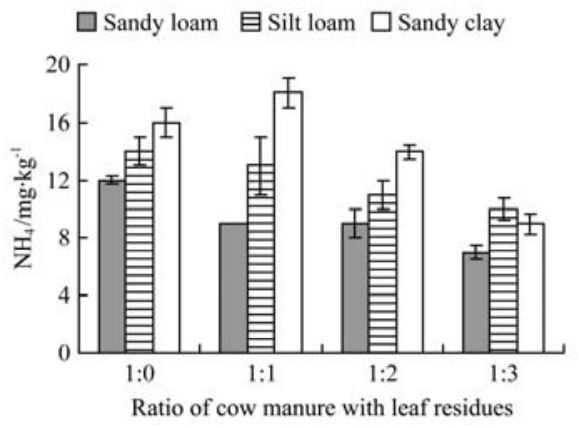

b. $\mathrm{NH}_{4}$

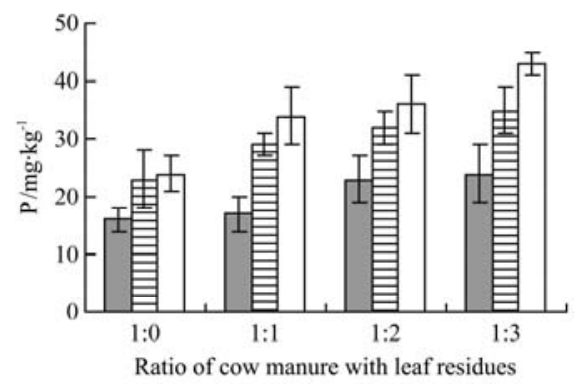

c. $\mathrm{P}$

Note: For this and subsequent figures and tables, LSD values signify the differences among manure ratios.

Figure 1 Changes in $\mathrm{NO}_{3}, \mathrm{NH}_{4}$ and $\mathrm{P}$ in soil amended with manure co-composted with maple leaf residues at different ratios

Available $\mathrm{K}$ concentrations varied with the ratio of compost applied and increased with the application of co-compost to the soil, especially the compost with increasing ratio of manure: plant litter (Figure 2). Generally the soil available K varied directly with the $\mathrm{K}$ in the composted manure amendments. For instance, the highest $\mathrm{K}$ concentration was observed in soil treated with manure containing higher amount of leaf residues, while the lowest $\mathrm{K}$ were in soil treated with manure alone (1:0). This suggests that the quality of organic matter might have affected the availability of $\mathrm{K}$ in the soil. Among amended soils, the available $\mathrm{K}$ varied in the descending order of sandy loam, sandy clayand silt loam. The fluctuation observed in the release of $\mathrm{K}$ could also be attributed to the variations in manures properties. Eneji et al. ${ }^{[19]}$ reported manure as a resource of plant macro- and micro-nutrients. The lower level of $\mathrm{K}$ in soil applied with the manure compost without plant litter could be due to the changes in organic matter.

Calcium concentration also varied with soil and ratio of plant litter but it generally increased with compost amendment (Figure 2). Maple leaf residues contained a significant amount of Ca (Table 1). Consequently, the extractable Ca content increased in the soil treated with the compost with higher manure: leaf litter ratios. The concentrations of Ca in soil (mg/kg) were 37 at $1: 0$ compost ratio, 45 at $1: 1$ ratio, 50 at 1:2 ratio and 56 at 1:3 ratio. Calcium increased by $21.6 \%, 35.1 \%$ and $51.3 \%$ with plant residues composted at ratios of 1:1, 1:2 and 1:3 in sandy loam soil. For the silt loam soil, the increases were $20 \%, 40 \%$ and $56.6 \%$ while for the sandy clay soil, they were $25.5 \%, 48.9 \%$ and $60.3 \%$, respectively. Calcium in the amended soils varied in the descending order of sandy clay, sandy loam and silt loam soil. The concentration of $\mathrm{Ca}$ in the soil was correlated with the total amount of $\mathrm{Ca}$ in the manure amendment (Table 3). Mandal et al. ${ }^{[20]}$ reported higher concentrations of $\mathrm{P}, \mathrm{K}, \mathrm{Mg}$ and $\mathrm{Ca}$ in poultry litter compost and these contents were correlated with the nutrient enriched pool of the compost. Irshad et al. ${ }^{[2]}$ reported higher biomass yield and promoted mineral concentrations of a crop in soil amended with composted manure. These results advocated that composted manure could be used to enhance the fertility of the nutrient in soils. Significance of compost in enhancing soil fertility via supplying nutrients for plant use was reported ${ }^{[2,21]}$.

The compost amendment increased soil Mg by 4, 16 and 20\% in sandy loam soil at ratios of 1:1, 1:2 and 1:3 (Figure 2). For the silt loam soil, it increased by $9.0 \%, 36.3 \%$ and $60.6 \%$ and for the sandy clay soil, it increased by $35 \%, 60 \%$ and $95 \%$, respectively. The changes in the extractability of $\mathrm{Mg}$ in manure amended soil could be related to alterations in elemental concentrations of the co-composts through microbial decomposition. The enhanced concentrations of above nutrients in soils with greater ratios could also be associated with the 
concentration effect due to leaves. Ano and Agwu ${ }^{[22]}$ reported a similar trend with animal manure that improved soil $\mathrm{pH}$ and increased the extractable Ca and Mg. Angelova et al. ${ }^{[23]}$ related $\mathrm{pH}$ with release of $\mathrm{Ca}$ and $\mathrm{Mg}$ from soil.
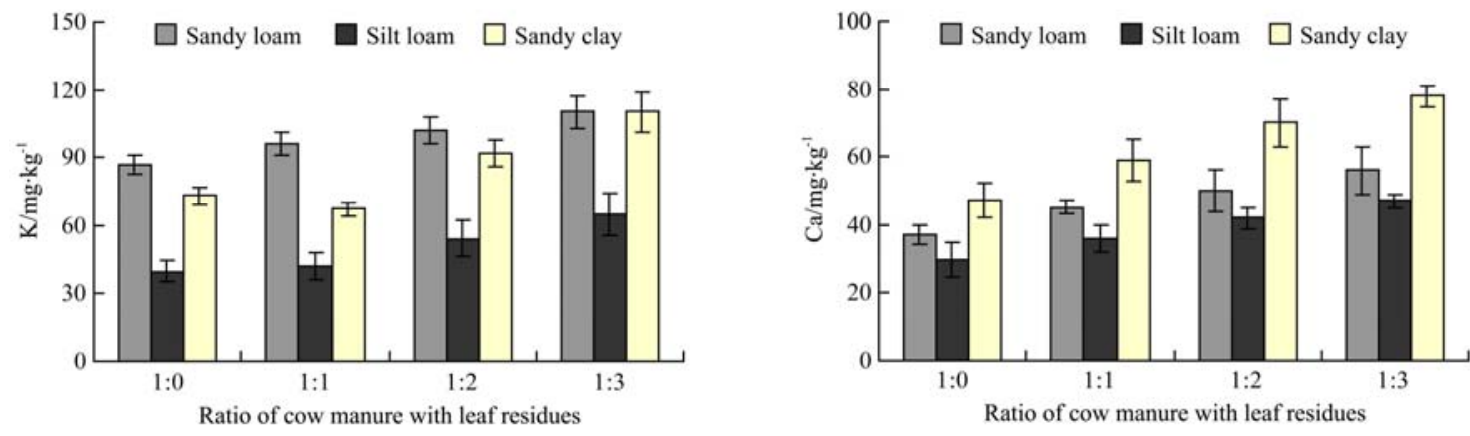

a. K
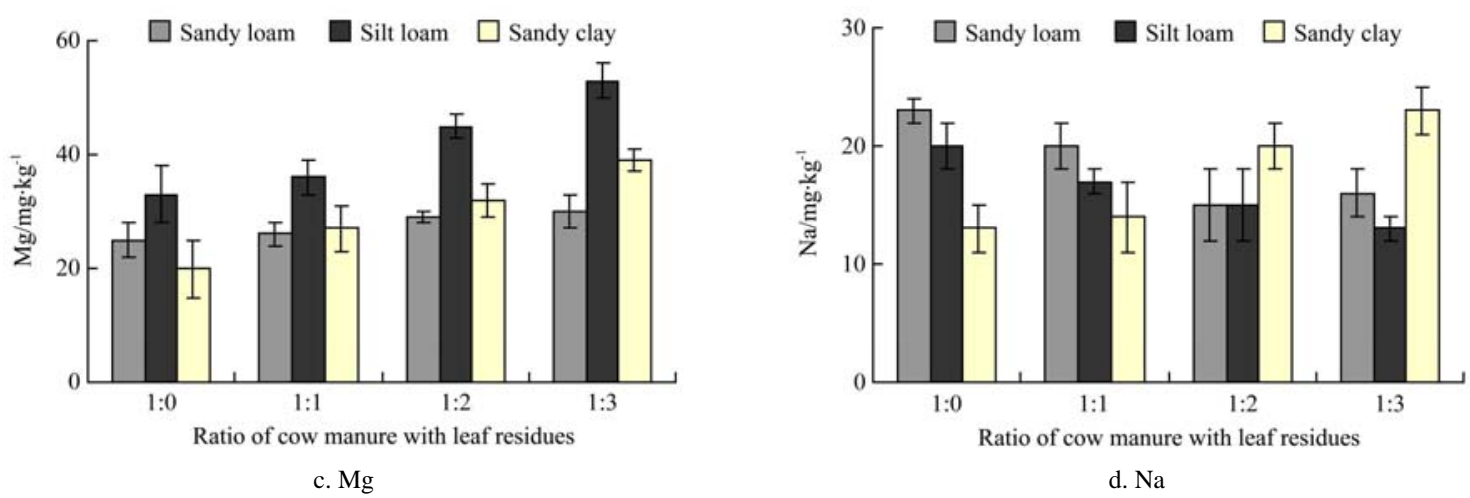

Figure 2 Changes in water extractable $\mathrm{K}, \mathrm{Ca}, \mathrm{Mg}$ and $\mathrm{Na}$ in soil amended with manure co-composted with maple leaf residues at different ratios

Table 3 Correlation between total elements in composted manure to the extractable elements in soils after amendment

\begin{tabular}{|c|c|c|c|c|c|c|c|c|c|c|c|}
\hline \multirow{2}{*}{$\begin{array}{l}\text { Elements } \\
\text { in soil }\end{array}$} & \multicolumn{11}{|c|}{ Amount of elements in composted manure } \\
\hline & Total P & Total K & Total Ca & Total Mg & Total Na & Total Zn & Total Mn & Total Fe & Total $\mathrm{Cu}$ & Total Cd & Total Ni \\
\hline $\mathrm{P}$ & $0.46^{*}$ & & & & & & & & & & \\
\hline $\mathrm{K}$ & & $0.67 * *$ & & & & & & & & & \\
\hline $\mathrm{Ca}$ & & & $0.77 * *$ & & & & & & & & \\
\hline $\mathrm{Mg}$ & & & & $0.63^{*}$ & & & & & & & \\
\hline $\mathrm{Na}$ & & & & & $0.55^{*}$ & & & & & & \\
\hline $\mathrm{Zn}$ & & & & & & $0.80^{* *}$ & & & & & \\
\hline $\mathrm{Mn}$ & & & & & & & $0.51^{*}$ & & & & \\
\hline $\mathrm{Fe}$ & & & & & & & & $0.45^{*}$ & & & \\
\hline $\mathrm{Cu}$ & & & & & & & & & $0.63 *$ & & \\
\hline $\mathrm{Cd}$ & & & & & & & & & & $0.56^{*}$ & \\
\hline $\mathrm{Ni}$ & & & & & & & & & & & $0.51^{*}$ \\
\hline
\end{tabular}

Note: $*$ and $* *$ indicate the significance at $p$ value of $<0.05$ and $<0.001$, respectively.

The availability of $\mathrm{Na}$ in soils decreased $(p<0.05)$ after amending with the co-composted material and as the amount of plant litter in the manure compost increased (Figure 2 and Table 4). Sodium concentrations decreased in soil after manure application with greater ratio of plant material i.e., 1:3 $<1: 2<1: 1$. The concentration in the soils varied in the ascending order of sandy clay, silt loam and sandy loam. Sodium concentrations in soils could be attributed to the concentration effect of the co-compost. Eneji et al. ${ }^{[24]}$ reported increased total Na with time of composting under aerobic and anaerobic conditions. Irshad et al. ${ }^{[2]}$ reported a fluctuation of the nutrients in the final compost due to the variations in the microbial activities. Increased extractable cations after organic waste amendment were reported by Mokolobate and Haynes ${ }^{[25]}$.

\subsection{Trace elements}

Irrespective of the treatments, the concentrations of trace elements across soils differed in the descending order of $\mathrm{Zn}, \mathrm{Mn}$, Fe, Cd, Cuand Ni (Tables 4 and 5). The addition of plant residues along with the manure altered the extractability of trace metallic elements in soils. All metal concentrations were reduced $(p<0.05)$ in soils by the addition of manure: leaf mixture. Soils incubated with the co-compost reduced the extractability of the trace elements. Concentrations of $\mathrm{Zn}$ in the sandy loam soil were reduced by $38.1 \%$ after the application of compost of maple residues (1:3). Silt loam soil reduced $\mathrm{Zn}$ value by $20.8 \%$ with maple residues (1:3). Similarly, the application of higher amount of composted maple plant residues to the sandy clay reduced $\mathrm{Zn}$ concentration by $18 \%$. Irrespective of the compost treatments, $\mathrm{Zn}$ concentration in soils 
varied in the order of sandy clay $>$ silt loam $>$ sandy loam. Irshad et al. ${ }^{[26]}$ reported that trace element contents in the saturated soil were governed by the type of amendment applied. The reduced Zn concentration with co-composted material could possibly be due to the elevated $\mathrm{pH}$ of the soil ${ }^{[27]}$ or the microbial decomposition leading to formation of inorganic humic substances that transformed $\mathrm{Zn}$ to organic fraction ${ }^{[28]}$. The organic amendments exhibited $\mathrm{Zn}$ with the threshold limit of $14-125 \mathrm{mg} / \mathrm{kg}$. Zinc reduction could also be associated with the mineralization of organic and lignocellulosic waste, which could precipitate $\mathrm{Zn}$ as inorganic compound. Overall, the co-compost was more efficient in reducing $\mathrm{Zn}$ availability than the cow manure compost.

Table 4 Analysis of variance (ANOVA) for the influence of manure on nutrient contents $\left(\mathrm{mg} \mathrm{kg}^{-1}\right)$ in soil applied with co-composted manure at different ratios

\begin{tabular}{|c|c|c|c|}
\hline \multirow{2}{*}{ Parameter } & Composted manure (C) & Soil (S) & Interaction $(\mathrm{C} \times \mathrm{S})$ \\
\hline & \multicolumn{3}{|c|}{ F-value } \\
\hline $\mathrm{NO}_{3}$ & $67.89 *$ & $245.78 * *$ & $23.80 *$ \\
\hline $\mathrm{NH}_{4}$ & $56.59 *$ & $356.62 * *$ & $39.76^{*}$ \\
\hline $\mathrm{P}$ & $26.51^{*}$ & $493.07 * *$ & $24.65^{*}$ \\
\hline $\mathrm{K}$ & $43.63^{*}$ & $419.60 * *$ & $34.87 *$ \\
\hline $\mathrm{Ca}$ & $39.54 *$ & $555.62 * *$ & $45.67 *$ \\
\hline $\mathrm{Mg}$ & $26.51^{*}$ & $493.07 * *$ & $12.73^{*}$ \\
\hline $\mathrm{Na}$ & $34.42 *$ & $399.71 *$ & $16.03^{*}$ \\
\hline $\mathrm{Zn}$ & $49.87 * *$ & $126.59 * *$ & $26.72 *$ \\
\hline Mn & $56.06 *$ & $281.37 *$ & $47.38 * *$ \\
\hline $\mathrm{Cu}$ & $45.57 * *$ & $447.46^{* *}$ & $36.13^{* *}$ \\
\hline $\mathrm{Ni}$ & $23.99 *$ & $445.46^{*}$ & $12.87 *$ \\
\hline $\mathrm{Cd}$ & $44.99 * *$ & 421.53* & NS \\
\hline EC & $12.92 *$ & $164.34 *$ & NS \\
\hline $\mathrm{pH}$ & $38.85 *$ & $207.36^{*}$ & $28.00 *$ \\
\hline
\end{tabular}

Note: $*$ and $* *$ indicate the level of significance at $p<0.05$ and $p<0.01$, respectively. NS indicates non-significance at $p<0.01$.

Table 5 Changes in heavy metal contents $\left(\mathrm{mg} \cdot \mathrm{kg}^{-1}\right)$ of soil amended with manure co-composted with maple plant residues

\begin{tabular}{|c|c|c|c|c|c|c|c|}
\hline Soil & $\begin{array}{l}\text { Manure/maple } \\
\text { litter mixture }\end{array}$ & $\mathrm{Zn}$ & $\mathrm{Mn}$ & $\mathrm{Fe}$ & $\mathrm{Cu}$ & $\mathrm{Ni}$ & $\mathrm{Cd}$ \\
\hline \multirow{5}{*}{$\begin{array}{c}\text { Sandy } \\
\text { loam }\end{array}$} & $1: 0$ & 42.7 & 25.2 & 12.1 & 3.8 & 1.6 & 0.7 \\
\hline & $1: 1$ & 37.3 & 20.7 & 10.1 & 3.4 & 1.7 & 0.8 \\
\hline & $1: 2$ & 30.3 & 17.8 & 8.4 & 2.8 & 1.1 & 0.5 \\
\hline & $1: 3$ & 26.7 & 15.6 & 6.3 & 2.5 & 1.0 & 0.5 \\
\hline & LSD (0.05) & 3.45 & 1.23 & 1.60 & 0.21 & 0.11 & .07 \\
\hline \multirow{5}{*}{ Silt loam } & $1: 0$ & 67.8 & 35.8 & 18.1 & 4.6 & 1.9 & 0.8 \\
\hline & $1: 1$ & 63.4 & 30.4 & 16.2 & 4.2 & 1.7 & 0.9 \\
\hline & $1: 2$ & 56.8 & 27.5 & 14.5 & 3.7 & 1.4 & 0.9 \\
\hline & $1: 3$ & 53.4 & 22.6 & 12.9 & 2.7 & 1.5 & 0.7 \\
\hline & $\operatorname{LSD}(0.05)$ & 4.34 & 3.44 & 1.78 & 0.56 & 0.16 & 0.08 \\
\hline \multirow{5}{*}{$\begin{array}{c}\text { Sandy } \\
\text { clay }\end{array}$} & $1: 0$ & 78.7 & 54.7 & 26.5 & 5.1 & 1.8 & 0.8 \\
\hline & $1: 1$ & 74.6 & 46.8 & 21.3 & 4.7 & 1.6 & 0.9 \\
\hline & $1: 2$ & 70.7 & 40.2 & 18.8 & 3.8 & 1.2 & 0.7 \\
\hline & $1: 3$ & 64.3 & 37.3 & 13.9 & 3.0 & 1.0 & 0.2 \\
\hline & LSD (0.05) & 4.54 & 3.89 & 1.83 & 0.62 & 0.18 & 0.06 \\
\hline
\end{tabular}

Higher concentration of Mn was observed in soil supplemented with manure without plant litter. The Mn concentration was reduced by $40 \%$ with the application of co-composted maple residues (1:3) in sandy loam soil as compared to the manure compost of 1:0. The application of manure co-composted with maple residues at 1:0, 1:1, 1:2 and 1:3 provide Mn concentrations of $35.8 \mathrm{mg} / \mathrm{kg}, 30.4 \mathrm{mg} / \mathrm{kg}, 27.5 \mathrm{mg} / \mathrm{kg}$ and $22.6 \mathrm{mg} / \mathrm{kg}$, respectively in the silt loam soil. In the sandy clay soil, the concentrations were $54.7 \mathrm{mg} / \mathrm{kg}, 46.8 \mathrm{mg} / \mathrm{kg}, 40.2 \mathrm{mg} / \mathrm{kg}$ and 37.3 $\mathrm{mg} / \mathrm{kg}$, respectively. Soils amended with only cow manure compost showed higher Mn level because of the higher Mn in the manure product. The co-compost reduced the water extractable fraction of Mn which varied in the soil in the ascending order of sandy clay, silt loamand sandy loam (Table 5). This suggests that the co-composted manure acted more as a sink than a source of heavy metals when applied to soils.

Iron concentration in soils reflected an inverse relationship with manure amendments (Table 5). Irrespective of the type of soil, the manure treatments effectively reduced the extractability of Fe from soil. There was a lower Fe concentration in soil amended with compost containing higher amount of plant litter. Lower Fe concentration was found in sandy loam soil $(6.3 \mathrm{mg} / \mathrm{kg})$ amended with co-compost with higher ratio of maple leaf residues than the cow manure treatment (1:0) where the concentration was $17.1 \mathrm{mg} / \mathrm{kg}$. The lower concentration of Fe in soils may reflect the total Fe contents initially present in the waste materials composted at different ratios. The reduction in the release of the Fe from manure amended soil could be related to the changes in soil properties such as $\mathrm{pH}$, adsorption and cation exchange capacity, which may have affected Fe solubilization. Within a soil, additional variation is associated with the type of soil and plant material used for composting. Angelova et al. ${ }^{[23]}$ reported a contrasting trend of increased Fe availability with vermicompost amendment. Pare et al. ${ }^{[29]}$ suggested that the stabilized organic matter has greater affinity to form complexes with metal ion species and restricted the mobility and bioavailability of the metals to the plants.

Adding the composted manure to the soil especially with the higher ratios of leaf litter apparently decreased the release of $\mathrm{Cu}$ compared with the soil applied with the manure amendment without leaf litter (1:0). Copper concentrations in the sandy loam soil amended with the manure of plant residues after co-compost at $1: 0$ and $1: 3$ ratios were $3.8 \mathrm{mg} / \mathrm{kg}$ and $2.5 \mathrm{mg} / \mathrm{kg}$. In silt loam soil after amendment with the co-compost at ratios of 1:0, 1:1, 1:2 and $1: 3$, the $\mathrm{Cu}$ concentrations were $4.6 \mathrm{mg} / \mathrm{kg}, 4.2 \mathrm{mg} / \mathrm{kg}, 3.7 \mathrm{mg} / \mathrm{kg}$ and $2.7 \mathrm{mg} / \mathrm{kg}$. Soil concentration of $\mathrm{Cu}$ remained within the threshold limit of $3-20 \mathrm{mg} / \mathrm{kg}^{[30]}$. Increased $\mathrm{Cu}$ concentration in soil amended with manure compost was reported previously ${ }^{[31]}$. Compost of maple residues decreased the available $\mathrm{Cu}$ to $2.5 \mathrm{mg} / \mathrm{kg}, 2.7 \mathrm{mg} / \mathrm{kg}$ and $3.0 \mathrm{mg} / \mathrm{kg}$ in sandy loam, silt loam and sandy clay soils. The reduction in $\mathrm{Cu}$ content could be due to the changes of organic matter into stable compound that bind more $\mathrm{Cu}$ in the form of complexes. A reduced $\mathrm{Cu}$ level following an organic amendment was reported by Sabir et al. ${ }^{[32]}$. Hsu and $\mathrm{Lo}^{[33]}$ reported a reduced leaching of $\mathrm{Cu}, \mathrm{Mn}$, and $\mathrm{Zn}$ from composted manure, which was attributed to their interactions with the organic material in the compost. However, fresh or immature composts had a higher leaching potential of $\mathrm{Cu}$ than mature composts.

A reduction in extractable Ni was noticed in soils after manure treatments regardless of the ratio of manure: litter (Table 5). The application of compost with elevated content of leaf litter reduced the extractability of $\mathrm{Ni}(p<0.05)$ from the soils. The sandy loam soil amended with co-compost (1:3) had a Ni concentration of only $1.0 \mathrm{mg} / \mathrm{kg}$ compared with $1.6 \mathrm{mg} / \mathrm{kg}$ when amended with manure compost (1:0). In the amended silt loam soil, application of compost reduced the $\mathrm{Ni}$ concentration to $1.5 \mathrm{mg} / \mathrm{kg}$ compared with 
$1.9 \mathrm{mg} / \mathrm{kg}$, while in the sandy clay soil it reduced from 1.8 to 1.0 . Karaca $^{[31]}$ reported a reduced phytoavailable $\mathrm{Ni}$ due to the application of farmyard manure and related this to the formation of organic complexes of insoluble Ni. Halim et al. ${ }^{[34]}$ showed a reduction in the DTPA-Ni with incubation time and attributed it to its immobilization with humified organic matter in soil.

The application of co-composted materials effectively reduced the available Cd level. Cadmium concentrations varied according to composting ratio in the descending order of 1:0, 1:1, 1:2 and 1:3. The reduced concentrations of trace elements in soils with greater litter ratios could be associated with the dilution effect due to leaves. The residues of trace elements in soils generally mirrored their contents in the amendments. The concentrations of trace elements in the soils were within critical limits after amendment with the co-compost. The permissible limits of $\mathrm{Cu}, \mathrm{Zn}, \mathrm{Ni}$ and $\mathrm{Cd}$ have been reported as 3-20 mg/kg, 14-125 mg/kg, 4-50 mg/kg and $0.3-0.7 \mathrm{mg} / \mathrm{kg}$, respectively ${ }^{[3]}$. The significant reduction in heavy metal content in soil following the application of composted manure with maple residue relative to sole cow manure indicated that co-composting of cow manure with maple residue may be a viable technique for reducing the risk of heavy metal contamination of both soils and waters when livestock manures are used as agricultural fertilizers.

The availability of heavy metals in soil was strongly influenced by the amount and quality of organic matter which may interact with the heavy metals, forming complexes and chelates of varying stability ${ }^{[35]}$. The decline in the extractable $\mathrm{Cd}$ in soil could possibly be due to the higher cation exchange capacity (CEC) of organic matter and its greater tendency to form chelate complexes to hold/bind more Cd. Karaca ${ }^{[31]}$ observed a decreasing trend of Cd with the application of mushroom compost and grape marc. The impact of organic amendments on heavy metal solubility depends greatly upon the degree of the humification of organic matter and their effect on soil $\mathrm{pH}^{[36]}$. The amount of an element in the soil solution was believed to depend on the equilibrium between the soil solution and solid phase, with $\mathrm{pH}$ playing the decisive role ${ }^{[37]}$. Depending on soil properties like $\mathrm{pH}$, cation exchange capacity and clay fraction, humic acid from organic amendments not only form different complexes with each metal, but also bound them in the exchangeable forms, affecting each metal differently. Some metals are bound and become unavailable whilst others are bound and rendered readily available ${ }^{[38]}$. Metal ions are usually less soluble at high $\mathrm{pH}$ and are therefore less bio-available to the plant $^{[39]}$.

\subsection{Soil EC and $\mathrm{pH}$}

The EC of the sandy loam soil was $2.0 \mathrm{dS} / \mathrm{m}$ after amending with manure composted (1:0) as compared to $2.5 \mathrm{dS} / \mathrm{m}$ in the soil amended with co-compost (1:3) (Table 6). In sandy clay soil, the amendment with co-compost at ratios of 1:0, 1:1, 1:2 and 1:3 exhibited EC values of $1.8 \mathrm{dS} / \mathrm{m}, 1.9 \mathrm{dS} / \mathrm{m}, 2.4 \mathrm{dS} / \mathrm{m}$ and $2.5 \mathrm{dS} / \mathrm{m}$, respectively. The EC of soils increased with the application of compost. Eneji et al. ${ }^{[19]}$ reported increases in EC level of soils according to the type of manure applied and related the differences in EC values to the content of salts from the manures. Gallardo-Lara and Nogales ${ }^{[40]}$ reported enhanced salt content as well as electrical conductivity after fertilization with composts. Total soluble salts and Na adsorption ratio in the soil significantly increased with manure amendments ${ }^{[41]}$. Acidic as well as alkaline soils showed an increased trend of EC particularly when organic materials of varying nature were applied to the soil ${ }^{[42,43]}$.

Increases in soil $\mathrm{pH}$ followed the amendment with co-compost.
The manure compost had slightly alkaline (pH7.1-7.6) possibly on account of the high amount of basic cations it contained. Enhanced $\mathrm{pH}$ after soil amendment with composted poultry manure has been reported ${ }^{[20,44,45]}$. Roy and Kashem ${ }^{[46]}$ reported similar trend of increment in $\mathrm{pH}$ following soil incubation with different animal manures. Organic amendment increased the $\mathrm{pH}$ of contaminated soils ${ }^{[32,47]}$.

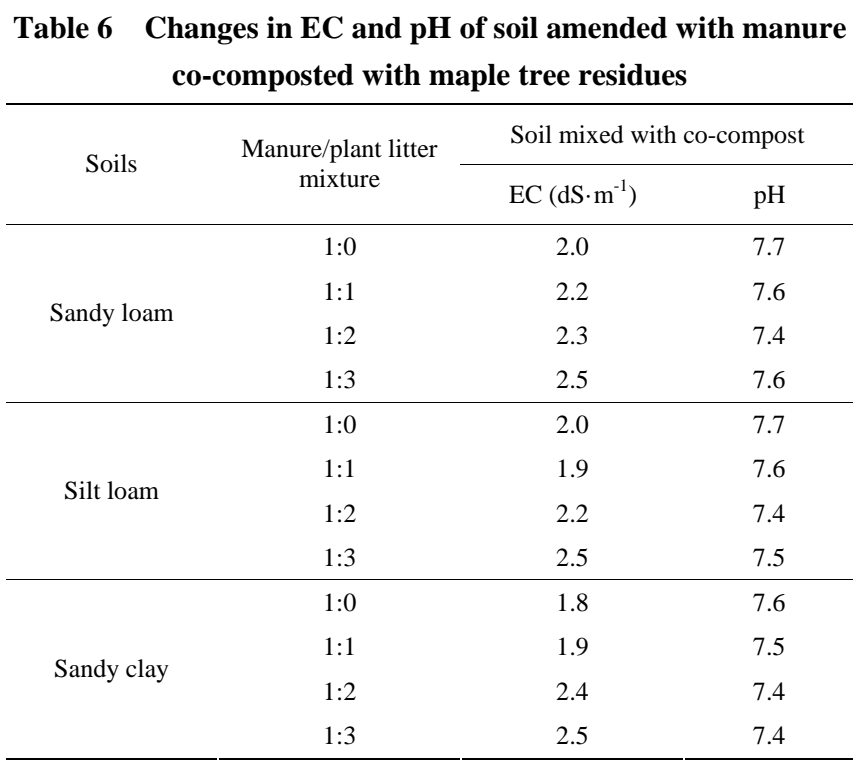

\section{Conclusions}

Changes in the plant nutrients in soils were highly dependent on the soil and manure amendment. Extractability of nutrients from soils amended with co-composted manure samples was substantially affected by the ratio of co-composted materials. The study generally found increased concentrations of $\mathrm{P}, \mathrm{Ca}, \mathrm{Mg}$, $\mathrm{K}$ and decreased concentrations of $\mathrm{NO}_{3}{ }^{-}, \mathrm{NH}_{4}{ }^{+}$, trace elements in the amended soils with greater ratio of manure: litter. Since trends in the soils and amendments were similar, it is concluded that an increase or decrease of nutrient ions in soil was likely to be directly linked with either a concentration or a dilution effect of increasing ratios of litter. Soil amendment with the co-compost would thus enhance the availability of macro-nutrients and reduce the availability of trace-elements, thereby limiting the possibility of metal ion export to the environment. Thus, the use of co-composted manure in place of animal manure alone in soils would be more beneficial for sustainable crop production.

\section{[References]}

[1] Duffera M, Robarge W P, Mikkelsen R L. Estimating the availability of nutrients from processed swine lagoon solids through incubation studies. Bioresour. Technol., 1999; 70: 261-268.

[2] Irshad M, Gul S, Eneji A E, Anwar Z, Ashraf M. Extraction of heavy metals from manure and their bioavailability to spinach (Spinacia oleracea L.) after composting. J. Plant Nutr., 2014, 37: 1661-1675.

[3] Edwards D R, Daniel T C. Environmental impacts of on-farm poultry waste disposal: A Review. Bioresour. Technol., 1992; 41: 9-33.

[4] Hao X, Godlinski F, Chang C. Distribution of phosphorus forms in soil following long-term continuous and discontinuous cattle manure applications. Soil Sci. Soc. Am. J., 2008; 72: 90-97.

[5] Zhang Y, He Y. Co-composting solid swine manure with pine saw dust as organic substrate. Bioresour. Technol., 2006; 97: 2024-2031.

[6] Daigle J Y, Mathur S P, Arseneault A. La tourbe de sphaignedans le compost age: une solution a` deuxproble`mes. In: Overend RP, Jeglum J. (eds.), Proceedings of peat and peat lands. Symposium 89, International Peat Society, 6-10. Québec (Qc) Canada, 1989; pp 64-66. 
[7] He X T, Logan T J, Traina S J. Physical and Chemical characteristics of selected US municipal solid waste composts. J. Environ. Qual., 1995; 24: 543-552.

[8] Chang H Y, Ahmad O H, Kassim S, Majid N M A. Co-composting of pineapple leaves and chicken slurry. Int. J. Recycl. Org. Waste Agric., 2013; 2: 1-8.

[9] Barrington S, Choinière D, Trigui M. Effect of carbon source on compost nitrogen and carbon losses. Bioresour. Technol., 2002; 83: 189-194.

[10] Raviv M, Medina S, Karasnovsky A. Conserving nitrogen during composting. Biocycle, 2002; 43(9): 48-51.

[11] Ogunwande G A, Osunade J A, Adekalu K O, Ogunjimi L A O. Nitrogen loss in chicken litter compost as affected by carbon to nitrogen ratio and turning frequency. Bioresour. Technol., 2008; 99: 7495-7503.

[12] Michel F C J, Pecchia J A, Rigot J, Keener H M. Mass and nutrient losses during composting of dairy manure with sawdust versus straw amendment. Compost Sci. Utiliz., 2003; 12: 323-334.

[13] Petric I, Sestan A, Sestan I. Influence of wheat straw addition on composting of poultry manure. Process Safety Environ. Protect., 2009; 78: 206-212.

[14] Dahshan H, Abd- Elall A M M, Abd-El-Kader M A, Megahed A M. Field-scale management and evaluation of recycled cattle manure solids from livestock in Nile Delta ecosystem. Afric. J. Agric. Res., 2013; 8: 2829-2836.

[15] Nelson D W, Sommers L E. Total carbon, organic carbon and organic matter. In A. L. Page, R. H. Miller, D. R. Keeney (Eds.), Methods of Soil Analysis. Part 2. Chemical and Microbiological Properties, ASA, SSSA, Madison, WI, USA, 1982; pp.539-580.

[16] Miller R O. Nitric-perchloric acid wet digestion in an open vessel, In: Kalra Y. Ed. Handbook of reference methods for plant analysis, CRC Press, Washington, DC. 1998.

[17] Anderson J M, Ingram J S I. Tropical soil biology and fertility, a handbook of methods, 2nd Ed. Wallingford, Oxon: CABI, 1993.

[18] Swift M J, Heal O W, Anderson J M. Decomposition in the Terrestrial Ecosystems. In Studies in Ecology, Blackwell: Oxford, UK, 1979.

[19] Eneji A E, Honna T, Yamamoto S, Masuda T, Endo T, Irshad M. The relationship between total and available heavy metals in composted manure. J. Sust. Agric., 2003; 23: 125-134.

[20] Mandal M, Chandran R S, Sencindiver J C. Amending subsoil with composted poultry litter-1: Effects on soil physical and chemical properties. Agron., 2013; 3: 657-669.

[21] Gul S, Naz A, Khan A, Nisa S, Irshad M. Phytoavailability and leachability of heavy metals from contaminated soil treated with composted livestock manure. Soil Sed. Contam. An Inter. J., 2016; 25 (2): 181-194.

[22] Ano A O, Agwu J A. Effect of animal manures on selected soil chemical properties. Nigerian J. Soil Sci., 2005; 15: 14-19.

[23] Angelova V R, Akova V I, Artinova N S, Ivanov K I. The effects of organic amendments on soil chemical characteristics. Bulgarian J. Agric. Sci., 2013; 19: 958-971.

[24] Eneji A E, Honna T, Yamamoto S, Masuda T. Influence of composting conditions on plant nutrient concentrations in manure compost. J. Plant Nutr., 2003; 26: 1595-1604.

[25] Mokolobate M, Haynes R. Comparative liming effect of four organic residues applied to an acid soil. Biol. Fertil. Soil, 2002; 35: 79-85.

[26] Irshad M, Yamamoto S, Honna T. Trace elements solubilization in waste amended saline-sodic conditions. J. Food Agric. Environ. 2004; 2: 254-258.
[27] Shuman L M. Organic waste amendments effect on zinc fractions of two soils. J. Environ. Qual., 1999; 28: 1442-1447.

[28] Nomeda S, Valdas P, Chen S Y, Lin J G. Variations of metal distribution in sewage sludge composting. Waste Manage, 2008; 28: 1637-1644.

[29] Paré T, Dinel H, Schnitzer M. Extractability of trace metals during co-composting of biosolids and municipal solid wastes. Biol. Fertil. Soils, 1999; 29: 31-37.

[30] BodSch Bundes-Bodenschutzverordnung. (Federal Soil Protection Rule) in Boden- schutz (Soil Protection) Erich Schmidt Verlag Berlin. 1998.

[31] Karaca A. Effect of organic wastes on the extractability of cadmium, copper, nickel, and zinc in soil. Geoderma 2004; 122: 297-303.

[32] Sabir M, Ghafoor A, Saifullah, Rehman M Z, Murtaza G. Effects of organic amendments and incubation time on extractability of $\mathrm{Ni}$ and others metals from contaminated soils. J. Agric. Sci., 2008; 45: 18-24.

[33] Hsu J H, Lo S L. Characterization and extractability of copper, manganese, and zinc in swine manure composts. J. Environ. Qual, 2000; 29: 447-453.

[34] Halim M, Conte P, Piccolo A. Potential availability of heavy metals to phyto-extraction from contaminated soils induced by exogenous humic substances. Chemosph, 2003; 52: 265-275.

[35] Leita L, De Nobili M, Mondini C, Muhlbachova G, Marchiol L, Bragato G Contin M. Influence of inorganic and organic fertilization on soil microbial biomass, metabolic quotient and heavy metal bioavailability. Biol. Fertil. Soils, 1999; 28: 371-376.

[36] Wong J W C, Fang M. Effect of lime addition on sewage sludge composting process. Water Res., 2000; 34: 3691-3698.

[37] Shazia G, Naz A, Fareed I, Khan A, Irshad M. Speciation of heavy metals in livestock manure after an industrial co-composting process. Polish J. Chem. Technol., 2015; 17: 19-23.

[38] Stevenson F J. Humus Chemistry- Genesis, Composition, Reactions. 2nd ed., Wiley, New York, 1994

[39] Khoshgoftarmanesh A H, Kalbasi M. Effect of municipal waste leachate on soil properties and growth and yield of rice. Commun. Soil Sci. Plant Anal., 2002; 33: 2011-2020.

[40] Gallardo-Lara F, Nogales R. Effect of the application of town refuse compost on the soil-plant system: A review. Biol. Wastes, 1987; 19: 35-62.

[41] Chang C, Sommerfeldt T G, Entz T. Rates of soil chemical changes with eleven annual applications of cattle feedlot manure. Canad. J. Soil Sci., 1990; 70: 673-681.

[42] Sarwar G, Hussain N, Mujeeb F, Schmeisky H, Hassan G. Biocompost application for the improvement of soil characteristics and dry matter yield of Lolium perenne (Grass). Asian J. Plant Sci., 2003; 2: 237-241.

[43] Niklasch H, Joergensen R G. Decomposition of peat, biogenic municipal waste compost, and shrub/grass compost added in different rates to a silt loam. J. Plant Nutr. Soil Sci., 2001; 164: 365-369.

[44] Rasnake M, Sikora F, Murdock L. Nutrient accumulation and movement in soils following the use of poultry litter. In Animal, Agricultural and Food Processing Wastes, Proceedings of the Eighth International Symposium, Des Moines, USA, 9-11 Oct. 2000; pp. 562-567.

[45] Walker D J, Clemente R, Roig A, Bernal M P. The effects of soil amendments on heavy metal bioavailability in two contaminated Mediterranean soils. Environ. Pollut., 2003; 122: 303-312.

[46] Roy S, Kashem M A. Effects of organic manures in changes of some soil properties at different incubation periods. Open J. Soil Sci., 2014; 4: 81-86.

[47] Whalen J K, Chang C, Clayton G W, Carefoot J P. Cattle manure amendments can increase the $\mathrm{pH}$ of acid soils. Soil Sci. Soc. Am. J., 2000; 64: 962-966. 